\title{
Comparison of Renewable Energy Sources in ‘New’ EU Member States in the Context of National Energy Transformations
}

\author{
Agnieszka Wałachowska ${ }^{1, *(D)}$ and Aranka Ignasiak-Szulc ${ }^{2}$ (D) \\ 1 Faculty of Management and Economics, Gdansk University of Technology, Gabriela Narutowicza 11/12 St., \\ 80-233 Gdańsk, Poland \\ 2 Faculty of Economic Sciences and Management, Nicolaus Copernicus University in Toruń, Gagarina 11, \\ 87-100 Torun, Poland; aranka@umk.pl \\ * Correspondence: agnwalac@pg.edu.pl
}

Citation: Wałachowska, A.; Ignasiak-Szulc, A. Comparison of Renewable Energy Sources in 'New' EU Member States in the Context of National Energy Transformations. Energies 2021, 14, 7963.

https://doi.org/10.3390/en14237963

Academic Editor: Jin-Li Hu

Received: 25 October 2021

Accepted: 25 November 2021

Published: 29 November 2021

Publisher's Note: MDPI stays neutral with regard to jurisdictional claims in published maps and institutional affiliations.

Copyright: (c) 2021 by the authors. Licensee MDPI, Basel, Switzerland. This article is an open access article distributed under the terms and conditions of the Creative Commons Attribution (CC BY) license (https:// creativecommons.org/licenses/by/ $4.0 /)$.
Abstract: The European Union strives to create sustainable, low-carbon economies; therefore, energy policies of all member states should move towards renewable energy sources (RES). That concerns also the so-called new EU member states. These countries, on the one hand, are characterized by significant historical similarities in terms of post-communist legacy and adopted development strategies linked with the EU membership, and on the other hand, by significant social, economic and environmental differences resulting from different transformation and development paths and conditions. The question remains how the selected countries should cope with actions in the field of national energy transformations to confront the multiple challenges linked to assuring a significant level of sustainable development. In order to be successful, it is necessary to conduct an effective and rapid changes in the energy industry, which should be preceded by an analysis of the differentiation of countries in terms of their potentials. The results of such analyses should be helpful in selecting the most appropriate strategies for transformation of the described industry. Therefore, the purpose of the article is to assess the new EU member states for RES diversification and identify similar subgroups of countries using cluster analysis, taking into account the percentage share of individual renewable energy sources in total renewable energy production. This was done for the years 2010, 2015 and 2019 which should allow us to demonstrate the differences between them as a group and also reveal changes recorded over time for a single country. Ward's method was used for the analysis. The presented approach to the analysis of energy production enabled the acquisition of new knowledge in this field and supported the assessment of the current state of RES. The results obtained can be used in countries of comparable specificity to undertake activities of similar nature in relation to internal energy production, technological development or common energy policy.

Keywords: renewable energy sources (RES); energy transformation; the new EU member states; cluster analysis; Ward's method

\section{Introduction}

In the currently ongoing processes of globalization, closely related with the dynamics of socio-economic changes, one of the main problems faced by countries in almost every region of the world is the growing importance of energy resources [1,2].

The rate of economic growth, unprecedented in history, forces the participants of the global economy to pay special attention to the uninterrupted satisfaction of energy needs [3]. The decades-long increase in demand for energy raises a number of challenges in terms of its acquisition, transmission, processing and distribution [4,5]. This gives a rise to complex contemporary problem which is based on the issue of energy security of individual countries and which is the foundation of the policy of most countries in the world. Such a broad subject matter, in fact, covering an infinite number of issues in the field of geopolitics, international economic relations, economics or technology, is the context for the issues discussed in this study related to the use of renewable energy by 
the post-communist countries-the so-called new member states that joined the structures of the European Union in 2004 (Czechia/Czech Republic, Estonia, Hungary, Lithuania, Latvia, Poland, Slovakia and Slovenia) and in 2007 (Bulgaria and Romania).

The area of Central and Eastern Europe (CEE) is one of the most important regions of Eurasia in geopolitical terms. The countries of this region have made a civilization leap over the past decades, carrying out an impressive political, social and economic transformation [6,7]. To a large extent, this process was achieved through integration with the European Union. This study focuses on the new EU member states due to the fact that these countries, thanks to their accession to the EU, received great impetus for the energy transformation. Along with the progressive changes in individual countries of the discussed region, traditional energy sources based on oil, coal, and natural gas are considered the most popular and effective drivers for economic development, but at the same time they are also harmful to the environment and to human health $[8,9]$. In the era of climate change, environmental degradation, and also growing public awareness of environmental concerns [10], there is a need to diversify traditional energy sources that rely on fossil fuels by new ecological sources [11,12]. This condition may be met by renewable energy sources (RES), that according to glossary used by EUROSTAT are energy sources that replenish (or renew-that is why they are sometimes called renewables) themselves naturally, i.e., those generated by natural resources that are not finite (exhaustible). They include, for example, biofuels (fuels from biomass) and renewable municipal waste (i.e., combustible renewables), and non-combustible renewables as wind, solar, hydropower, and geothermal energy sources, etc. Renewable energy may have some disadvantages or limitations (high upfront costs, storage capabilities, intermittency, etc.) but it can serve as a potential way to restore balance between economic growth and environmental quality $[13,14]$. In the countries located in the CEE, energy security issues (as ability to act as a unified bloc) may be still relatively more important compared with the countries located in the West (especially considering their relations with Russia and having in mind so called gas crisis in Ukraine in 2006) but with growing concern of climate change, the issues related with environmental protection and sustainability affect rapidly growing world economies with increasing energy demand, including economies of the European Union member states and CEE countries. The situation in individual member states differs significantly but the EU (treated as one entity) may be seen clearly as one of the largest greenhouse gas emitters [15], and coordination of climate policy is needed also on the community level. The basis for the European energy policy was introduced by the Treaty of Lisbon in Article 194 of the Treaty on the Functioning of the European Union [16]. Pursuing a green economy, mainly understood as a low-emission economy, means the EU's climate policy is largely focused on RES on the way to climate neutrality. Climate neutrality refers to zeroing greenhouse gas emissions, i.e., reducing their emissions from industry, transport, and energy sectors as much as possible and offsetting the emissions that could not be eliminated by increasing their removal. Under the 2015 Paris Agreement (COP21), the EU promotes an energy union aimed at building energy security and solidarity as well as a fully integrated internal market, supporting research and competitiveness, accelerating energy efficiency, and climate-oriented actions for a carbon-neutral EU economy by 2050. The latter is an objective of the European Green Deal (COM(2019)640 final). This ambitious package includes not just suggestions, member states have to follow distinctive paths when it comes to meeting their obligations under the renewable energy directives, including legally binding 2020 targets. A general target for increasing the share of renewable energy sources has been set, according to which it should reach at least $32 \%$ by 2030 in line with the EU climate and energy framework (20\% in 2020). The main reason for these actions is to provide EU consumers with safe, sustainable, competitive, and affordable energy. Charles Michel, the President of the European Council, said that "climate neutrality is no longer a question of choice, it is beyond doubt a necessity" [17].

To be successful in this field, it is necessary to carry out an effective and fast transformation of the energy industry process. Even though the EU as a whole is on track to 
meet its targets, the question is whether the generation of renewable energy at a given level is a challenge for selected new member states countries dependent on fossil fuels. It can be expected that some countries from the research area that generate energy from nuclear sources (Hungary, Czech Republic), i.e., from sources with zero emission of $\mathrm{CO}_{2}$, will be less inclined towards the development of RES. Undoubtedly, the new member states include countries whose share of energy from renewable sources was much more than 20\% already in 2019 (Estonia 32\%, Latvia 41\%) (Figure 1). Nonetheless, the Central and Eastern Europe countries also include those for which RES is still not sufficiently important, with the share of energy from renewable sources remaining low (Poland 12.2\%, Hungary $12.6 \%$ ) (Figure 1).

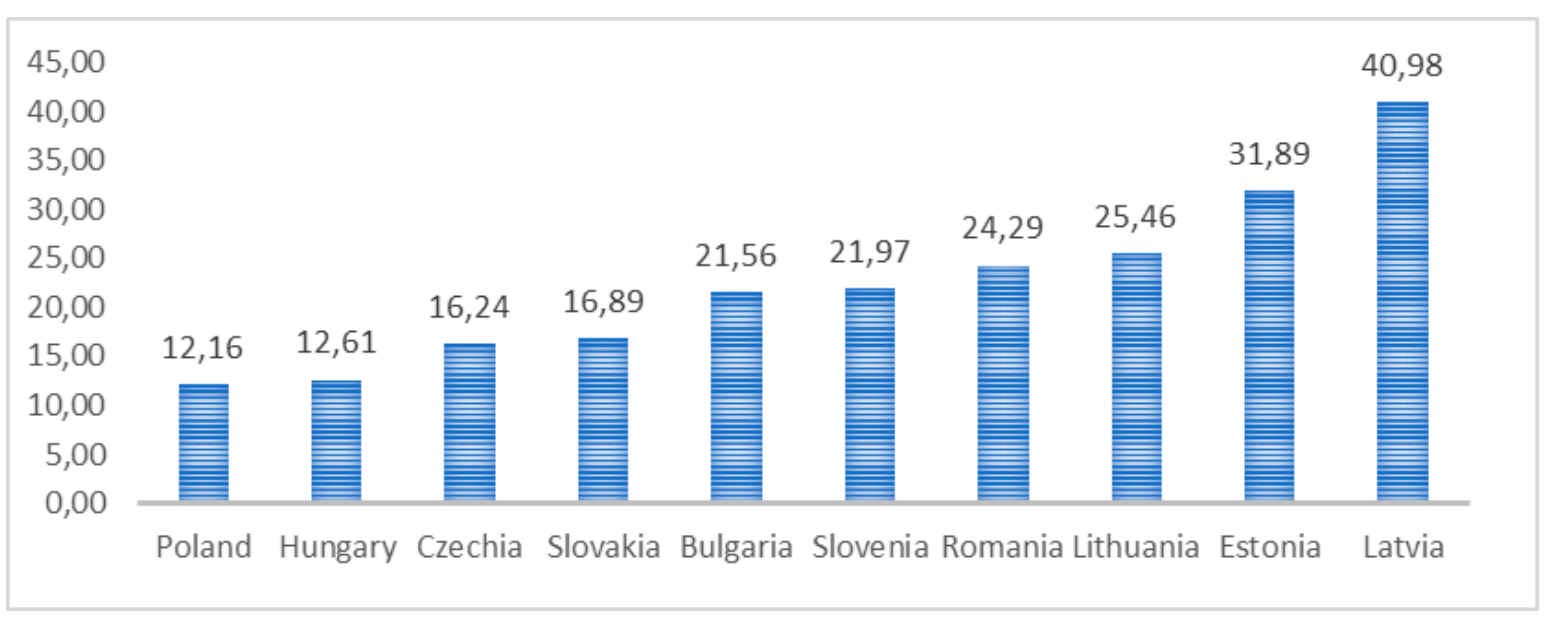

Figure 1. Share of energy from renewable sources in the new member states countries in 2019. Source: own calculations based on data from Eurostat (online data code: NRG_IND_REN_custom_716443).

The progressive European integration in the political, economic and social dimensions is still functioning in isolation from the energy transformation process, which as the foundation of security is implemented in various ways by individual member states. On the one hand, the inflow of capital from the EU helps to introduce innovations, new consumption patterns, diversification of energy sources with an emphasis on the largest possible share of energy from renewable sources. On the other hand, this process comes at a huge social cost. This element can be mitigated in the process of globalization, which affects the exchange of information between countries influencing the increase in public awareness and international integration of economies. That creates favorable conditions for more dynamic development, mostly for economic centers, both at national and regional level [18-22].

To take action for RES development in the examined countries, it is necessary to analyze their differences in terms of potential. These differences depend on the energy policies of individual countries as well as the environmental awareness of societies. The economic aspect is also important. It is undeniable that energy production from RES is considerably more expensive than from conventional sources. As a result of the high upfront costs, many new member states countries seem unable to cover them from their own resources, what limits the potential for renewable energy development in the area. The potential and availability of individual renewable energy sources are also of great importance. In order to find the most effective solutions to common problems, analyses have been carried out to identify similarities between new member states countries in terms of the structure of RES energy production. They usually include the eight major renewable energy sources: hydro, geothermal, wind, and solar as well as primary solid biofuels, biogases, renewable municipal waste, and liquid biofuels. The analysis indicates groups of the CEE countries with the highest similarly identified. So far, not a lot of analyses focusing on the new member states countries with these factors have been conducted in 
the literature, there are just single and very recent papers that include analyses of the EU indicating the specifics of the countries (or their groups) in the region [23]. Therefore, the approach used can be still be called new and the results of such analyses should support the implementation of the adopted strategies in the countries of the region. It is known that one of the main factors affecting the pace of changes is the amount of public spending on energy transition $[24,25]$; therefore, the pro-environment policy implemented and required to be continued by the EU must be adapted to the uniqueness of the new EU member states. In addition, the awareness of mutual similarities among new member states should promote cooperation and acceleration of actions towards energy transition.

Due to the exchange of information, the development of the energy system, including RES, is possible. In order to be able to take a holistic view of the energy transformation process in the discussed region, it is worth seeing the similarities and differences in RES production in surveyed countries. The aim of the paper is to analyze the level of diversification of renewable energy sources in three selected years for analysis $(2010,2015,2019)$ and to identify groups of similar countries due to the structure of the percentage share of individual renewable energy sources in the total production of renewable energy. The implementation of the goal allowed the countries to be organized in terms of the dominant role of selected energy sources. The assessment of the state of RES in the new member states countries in these three years also indicated possible directions of the state's policy in the field of the ongoing energy transformation. In addition, the obtained research results can be related to groups of countries where, due to the similarities in the nature of RES, they can take actions of a similar nature at the EU level with regard to internal energy production, technological development or common energy policy. The adopted research approach is proprietary due to the classification of countries in terms of the percentage share of individual renewable energy sources in the total production of renewable energy. Most of the research is carried out on the values of energy produced from selected RES (per capita or per GDP product), which may lead to erroneous conclusions. The paper presents Figure 1, which shows that selected countries currently differ significantly in terms of the share of energy production from RES in the total energy production. This means that the analysis of the similarity of countries in the context of comparing the value of energy production from selected RES should be performed carefully.

The paper is organized as follows: an overview of the related literature is provided in Section 2; the description of methods is included in Section 3, data are described in the Section 4, and results in the Section 5. Two final sections: include discussion (Section 6) and conclusions (Section 7).

\section{Literature Review}

The importance of renewable energy in the energy mix is increasingly recognized. Traditionally, literature reviews of the papers devoted to the issue have been based on the problem of sustainable development (SD) and strategies or policies of achieving it in the context of international or national goals [26,27]. SD is today a well-established term both in all territorial perspectives as it had been introduced already by 1970 by the United Nations and the most common definition was proposed by the Brundtland Commission of 1987 and the interdisciplinary discussions that followed the publication of Our Common Future [28-30]. They allowed SD policy to be distinguished from environmental policy as it can only be achieved by integration of environmental, social, and economic concerns and objectives, and it has given a fresh impetus for advancing both theoretical and practical aspects of SD. It became a guiding institutional principle and a policy goal, implemented also in the EU.

The advantages of renewable energy for the environment are undeniable and widely discussed in the world literature as RES are usually seen as an element that will contribute to mitigating climate change and the opportunity to achieve also other sustainability targets as RES technologies can facilitate social and economic development [31]. Therefore, there are also analyses concerning issues related to climate change prepared for the EU [32] and 
the CEE countries [33]. In order to address the sustainability challenges the considerations connected with environmental concerns are not only concentrated on ecosystem complexity but accompanied by social and economic impacts of RES in territorial [34] or general perspective [35]. As mentioned, energy policy is often perceived also in the energy security context [36-38] also as RES has the potential to improve energy security by making the system more resilient to disruptions.

As the energy sector is often seen as a key to economic development, there are numerous studies on the link between RES and various macroeconomic variables [39,40]. They often focus on the impact of RES on economic growth. In their studies, Ohler and Fetters [41] identify a two-way relationship between aggregate renewable energy and real GDP. Simultaneously, they argue that biomass, hydroelectric, and waste electricity generation have the largest impact on real GDP in the long-run. The findings of Kula [42] also support the existence of a long-term balanced relationship between renewable electricity consumption and GDP, while Anwar, Arshed and Kousar [43] argue that the impact of renewable electricity consumption on economic growth is positive and significant. As for measuring SD it is necessary to go beyond the quantitative indicators, a set of aggregate indicators of SD is usually suggested and widely discussed in the literature $[31,44,45]$. They have gained a lot of criticism due to the arbitrary character of procedures used in their construction, but one of the advantages of the development of such indicators is that they allow international comparability.

An international perspective is important here as issues related to climate change call for cross-border cooperation. The cooperation in the EU connected with Green Deal described above is important but in terms of the expansion of renewable energy is also significant and results in a possible increase in the efficiency of individual countries. Nevertheless, the studies show that the majority of European countries are yet to pursue any cooperation and wish to achieve the expansion objective in terms of renewable energy primarily through expansion within their own national borders [46,47]. On the other hand, history shows that new member states' energy security meant the pursuit of the highest self-sufficiency and independence compared to other entities. For several years, these countries have been transforming their economies at a different pace, with the aim of the marketisation of economic processes. Many changes are underway in the industry area, which is still energy-intensive and dependent on primary energy sources. Although transition economies are trying to become greener through the reduction of greenhouse gas emissions, they are doing so at different rates. Some of them, such as Estonia, Latvia or Lithuania, have undergone a drastic transformation, whereas others, such as Hungary or Slovenia, are making changes at a slower pace [48]. As noted by others, the large area of forestry land in Central Europe makes forest biomass and waste from the wood processing industry (sawdust, chips) or in a processed form (pellet, briquette) suitable for energy purposes, while the involvement of agriculture in building bioenergy production capacity, in particular the development and distribution of multiannual crops and their potential in new member states countries, is crucial for bioenergy in the long term [49].

The development of RES brings about challenges in terms of how to run energy policy as countries with a diversified level of RES offer incentives to advance RES [31] and obtain goals set at international, national, regional and local level. It must be more stable and, thus, more credible and clearer to citizens. This is the EU energy policy that is characterized by a high degree of social involvement in the ownership, management, and benefits of energy projects [50,51]. In addition, econometric analysis reveals a positive correlation between subsidies and the generation of motivated energy as well as installed capacity [24,52]. Bersalli, Menanteau and El-Methni [53] showed that promotional policies have a positive and statistically significant effect on RES investment.

Papers addressing the issue of renewable energy sources in the context of Europe mainly focus on the European Union [54-56]. Few of them focus on the uniqueness of Central and Eastern Europe countries [23], for which, for historical reasons, it is a challenge to change the regulatory system in order to allow entities not controlled by their 
governments to produce and transmit electricity. Recently, Pakulska [57] proved that for most of the CEE countries transformation towards a climate-neutral economy is challenging task. Papers focusing on the new member states countries often address a single country in terms of renewable energy for the near future $[58,59]$ or a specific renewable energy source of a selected country [60].

What is proved in the research presented above is that energy transition, aimed at replacing conventional energy sources with RES, what is more, is a complex process that depends on many factors, and the reasons for the uneven distribution of energy production from RES in new member states countries are diverse and include social, economic, and environmental (like issues connected with climate, hydrology and geology). The results also support the need to conduct a study that should focus not only on the absolute values of renewable energy, but also on other factors that may shape the volume and structure of such RES production in the future. Therefore, such an approach to this analysis appears to be fully justified.

The analysis of new member states countries in this study fills a gap in the existing literature and contributes to the discussion on the European Strategy 2020-2030 for the whole EU and especially for the countries of the region of Central and Eastern Europe-new member states. The approach adopted in this paper gives a broader view and considers the uniqueness of each new member states countries.

\section{Methods}

A wide group of methods that are used in the problems of multivariate comparative analyses are taxonomic methods, also commonly found under the term "cluster analysis" [61,62]. They deal with the rules and procedures for the classification of various types of objects. Taxonomies have many applications that span a variety of fields. For example, in economics and finance, taxonomies are used to group countries based on sets of development indicators or to recognize the level of regions development $[63,64]$. The most general division allows taxonomic methods to be converted to hierarchical methods (agglomeration and division) and grouping by the k-means method, where objects are assigned to k clusters and the number of clusters is determined by the researcher [65]. Among the agglomeration algorithms, Ward's method is widely used [66-68].

The research method applied in this paper is cluster analysis. Cluster analysis is a method used in multivariate comparative analyzes that breaks down a large group of objects into relatively homogeneous groups called clusters. In general, cluster analysis is used to classify $\mathrm{n}$ objects, while these objects are described with $\mathrm{k}$ statistical features. In the analysis of clusters, the similarity or dissimilarity of objects is taken into account, and on this basis groups of objects (clusters) that are mutually exclusive are distinguished. The objects assigned to each cluster are similar to each other in terms of the values of all $\mathrm{k}$ variables.

The article uses the method of Ward [69], because it is the most frequently used method in economic research $[61,70,71]$. In Ward's method, the sum of squares within groups is minimized, where in the first stage of grouping, each object forms an independent cluster. In the next steps, the standalone clusters are grouped into superior clusters based on the selected distance measure. In the last step, all statistical objects are combined into one cluster [61].

The use of cluster analysis has allowed us to separate homogeneous subsets of population objects, which are new member states countries, based on variables describing the examined countries, i.e., the value of energy produced from RES commonly used in Eurostat analyses. The main idea behind cluster analysis is to group objects (countries) in such a way that the objects included in the same group are characterized by a significant similarity and at the same time they differ from objects from other groups as much as 
possible. To do so, the Euclidean distance was used as a measure of distance, which is given by:

$$
d(x, y)=\sqrt{\sum_{i=1}^{p}\left(x_{i}-y_{i}\right)^{2}},
$$

where $x=\left(x_{1}, \ldots, x_{p}\right)$ and $y=\left(y_{1}, \ldots, y_{p}\right)$, and in this case $p=8$, which is the number of variables that characterise a country. The greater the distance between two countries, the more diverse they are. As a result, a cluster includes countries close to each other and far away from others that form separate clusters.

Before the determination of distance matrices, the variables were standardized using the formula:

$$
z_{i}=\frac{x_{i}-\bar{x}}{s_{x}}
$$

where $\bar{x}$ and $s_{x}$ refer to the mean and standard deviation of the sample.

The agglomerative hierarchical clustering algorithm was applied in the first step of analysis. The agglomeration method was Ward's method, which is used to minimize the sum of the squares of within-cluster variance. This resulted in a graphical illustration of the agglomeration pattern in the form of a diagram referred to as a dendrogram and the suggestion of the number of clusters to which the countries are to be assigned. In the second step of the analysis k-means non-hierarchical clustering was used. The optimal number of clusters was determined with the use of the Silhouette index [72-74]:

$$
S(u)=\frac{1}{n} \sum_{i=1}^{n} \frac{b(i)-a(i)}{\max \{a(i), b(i)\}}, S(u) \in[-1,1],
$$

where $u$ is the number of classes, $n$ is the object (country) number, $a(i)$ is the mean distance of the country with index $i$ from other countries belonging to class number $r, r=1, \ldots, u . b(i)$ is the mean distance of the country with index $i$ from other countries belonging to class number $s, s=1, \ldots, u$. The criterion based on the Silhouette index indicates the selection of the number of classes $u$, for which index $S(u)$ takes the maximum value.

The results obtained on the basis of Ward's method are most often presented in the form of a dendrogram. At the top of the dendrogram, all objects form one shared cluster. Moving to lower levels, successive clusters with a smaller number of objects are distinguished, where at the lowest level all objects form separate clusters $[71,75,76]$.

\section{Data}

Data on the structure of RES energy production for the new member states was taken from the Eurostat database for 2010 (Table 1), 2015 (Table 2) and 2019 (Table 3).

Table 1. Structure of energy production from renewable energy sources (RES) in the new member states in 2010.

\begin{tabular}{cccccccccc}
\hline Countries & Hydro & Geothermal & Wind & $\begin{array}{c}\text { Primary } \\
\text { Solid } \\
\text { Biofuels }\end{array}$ & Biogases & $\begin{array}{c}\text { Renewable } \\
\text { Municipal } \\
\text { Waste }\end{array}$ & $\begin{array}{c}\text { Liquid } \\
\text { Biofuels }\end{array}$ & Solar & Total \\
\multicolumn{10}{c}{ Gigawatt-Hour } \\
\hline Bulgaria & 5692.52 & 0.00 & 681.37 & 19.74 & 15.50 & 0.00 & 0.00 & 14.87 & 6423.99 \\
Czechia & 3380.58 & 0.00 & 335.49 & 1492.24 & 634.66 & 35.59 & 0.00 & 615.70 & 6494.26 \\
Estonia & 26.88 & 0.00 & 276.99 & 729.82 & 10.19 & 0.00 & 0.00 & 0.00 & 1043.88 \\
Latvia & 3520.51 & 0.00 & 49.06 & 8.41 & 56.69 & 0.00 & 0.00 & 0.00 & 3634.66 \\
Lithuania & 1295.00 & 0.00 & 224.00 & 116.00 & 31.00 & 0.00 & 0.00 & 0.00 & 1666.00 \\
Hungary & 188.38 & 0.00 & 533.79 & 2034.28 & 117.32 & 144.86 & 0.00 & 0.85 & 3019.49 \\
Poland & 3488.14 & 0.00 & 1664.34 & 5905.21 & 398.38 & 0.00 & 0.90 & 0.00 & $11,456.97$ \\
Romania & $20,242.98$ & 0.00 & 306.35 & 109.84 & 0.65 & 0.00 & 0.00 & 0.04 & $20,659.86$ \\
Slovenia & 4702.96 & 0.00 & 0.00 & 119.53 & 97.35 & 0.00 & 0.00 & 12.86 & 4932.69 \\
Slovakia & 5649.00 & 0.00 & 6.00 & 606.00 & 34.00 & 22.00 & 0.00 & 16.94 & 6333.94 \\
\hline
\end{tabular}


Table 2. Structure of energy production from RES in the new member states in 2015.

\begin{tabular}{cccccccccc}
\hline Countries & Hydro & Geothermal & Wind & $\begin{array}{c}\text { Primary } \\
\text { Solid } \\
\text { Biofuels }\end{array}$ & Biogases & $\begin{array}{c}\text { Renewable } \\
\text { Municipal } \\
\text { Waste }\end{array}$ & $\begin{array}{c}\text { Liquid } \\
\text { Biofuels }\end{array}$ & Solar & Total \\
\hline \multicolumn{7}{c}{ Gigawatt-Hour } \\
\hline Bulgaria & 6146.54 & 0.00 & 1451.51 & 151.08 & 119.11 & 0.00 & 0.00 & 1383.27 & 9251.51 \\
Czechia & 3070.77 & 0.00 & 572.61 & 2091.50 & 2610.96 & 86.65 & 0.00 & 2263.85 & $10,696.34$ \\
Estonia & 26.60 & 0.00 & 715.00 & 710.00 & 50.00 & 58.00 & 0.00 & 0.00 & 1559.60 \\
Latvia & 1860.36 & 0.00 & 147.14 & 377.78 & 391.71 & 0.00 & 0.00 & 0.24 & 2777.22 \\
Lithuania & 1024.00 & 0.00 & 810.00 & 318.00 & 86.00 & 42.00 & 0.00 & 73.00 & 2353.00 \\
Hungary & 233.71 & 0.00 & 693.32 & 1660.96 & 292.99 & 207.29 & 0.00 & 141.00 & 3229.27 \\
Poland & 2435.20 & 0.00 & $10,858.37$ & 9026.64 & 906.40 & 0.00 & 3.82 & 56.64 & $23,287.06$ \\
Romania & $17,006.55$ & 0.10 & 7062.93 & 462.27 & 60.78 & 0.00 & 0.00 & 1982.00 & $26,574.63$ \\
Slovenia & 4090.18 & 0.00 & 6.03 & 131.28 & 132.30 & 0.00 & 0.00 & 274.23 & 4634.02 \\
Slovakia & 4137.00 & 0.00 & 6.00 & 1099.00 & 541.00 & 22.00 & 0.00 & 506.00 & 6311.00 \\
\hline
\end{tabular}

Table 3. Structure of energy production from RES in the new member states in 2019.

\begin{tabular}{|c|c|c|c|c|c|c|c|c|c|}
\hline Countries & Hydro & Geothermal & Wind & $\begin{array}{l}\text { Primary } \\
\text { Solid } \\
\text { Biofuels }\end{array}$ & Biogases & $\begin{array}{c}\text { Renewable } \\
\text { Municipal } \\
\text { Waste }\end{array}$ & $\begin{array}{l}\text { Liquid } \\
\text { Biofuels }\end{array}$ & Solar & Total \\
\hline \multicolumn{10}{|c|}{ Gigawatt-Hour } \\
\hline Bulgaria & 3382.75 & 0.00 & 1316.99 & 1545.79 & 230.72 & 44.30 & 0.00 & 1442.47 & 7963.01 \\
\hline Czechia & 3174.69 & 0.00 & 700.01 & 2398.73 & 2528.08 & 104.85 & 0.00 & 2311.57 & $11,217.94$ \\
\hline Estonia & 19.00 & 0.00 & 687.00 & 1259.79 & 38.84 & 64.07 & 0.00 & 73.50 & 2142.20 \\
\hline Latvia & 2107.55 & 0.00 & 154.00 & 575.02 & 352.40 & 0.00 & 0.00 & 3.14 & 3192.11 \\
\hline Lithuania & 947.70 & 0.00 & 1499.40 & 330.70 & 154.40 & 48.10 & 0.00 & 91.10 & 3071.40 \\
\hline Hungary & 219.00 & 18.00 & 729.00 & 1769.00 & 318.00 & 137.00 & 0.00 & 1497.00 & 4687.00 \\
\hline Poland & 2664.88 & 0.00 & $15,106.76$ & 6441.15 & 1135.01 & 104.83 & 1.99 & 710.67 & $26,165.30$ \\
\hline Romania & $16,005.70$ & 0.00 & 6772.81 & 450.34 & 53.81 & 0.00 & 0.00 & 1777.62 & $25,060.27$ \\
\hline Slovenia & 4682.54 & 0.00 & 6.15 & 151.46 & 94.36 & 0.00 & 5.22 & 303.04 & 5242.76 \\
\hline Slovakia & 4571.00 & 0.00 & 6.00 & 1130.00 & 534.00 & 29.00 & 0.00 & 589.00 & 6859.00 \\
\hline
\end{tabular}

Then, the percentage share of eight individual variables describing the volume of energy production from selected renewable sources in total renewable energy was calculated for each year-2010 (Table 4), 2015 (Table 5) and 2019 (Table 6). Initial calculations pointed to strong differences in the levels of percentage share of individual renewable energy sources in total renewable energy from selected renewable sources. The significant differences of the new member states in terms of RES production structure are reflected by the high coefficient of variation of individual variables. Therefore, the presented average values for the percentage share of individual renewable energy sources in the total production of renewable energy, calculated for all countries, have a low cognitive value and only the cluster analysis performed in the further part of the article will allow for a proper comparison of selected countries. In addition, the correlation of the variables describing the countries was not high, which supported the applicability of the Euclidean distance to conduct cluster analysis.

Table 4. Percentage share of individual RES in total production in 2010.

\begin{tabular}{ccccccccc}
\hline Countries & Hydro & Geothermal & Wind & $\begin{array}{c}\text { Primary } \\
\text { Solid } \\
\text { Biofuels }\end{array}$ & Biogases & $\begin{array}{c}\text { Renewable } \\
\text { Municipal } \\
\text { Waste }\end{array}$ & $\begin{array}{c}\text { Liquid } \\
\text { Biofuels }\end{array}$ \\
\hline & & \multicolumn{9}{c}{$\begin{array}{c}\text { Solar } \\
\text { Bulgaria }\end{array}$} & 88.61 & 0.00 & 10.61 & 0.31 & 0.24 & 0.00 & 0.00 \\
Czechia & 52.05 & 0.00 & 5.17 & 22.98 & 9.77 & 0.55 & 0.00 \\
\hline
\end{tabular}


Table 4. Cont.

\begin{tabular}{|c|c|c|c|c|c|c|c|c|}
\hline Countries & Hydro & Geothermal & Wind & $\begin{array}{l}\text { Primary } \\
\text { Solid } \\
\text { Biofuels }\end{array}$ & Biogases & $\begin{array}{c}\text { Renewable } \\
\text { Municipal } \\
\text { Waste }\end{array}$ & $\begin{array}{l}\text { Liquid } \\
\text { Biofuels }\end{array}$ & Solar \\
\hline \multicolumn{9}{|c|}{$\%$} \\
\hline Estonia & 2.58 & 0.00 & 26.53 & 69.91 & 0.98 & 0.00 & 0.00 & 0.00 \\
\hline Latvia & 96.86 & 0.00 & 1.35 & 0.23 & 1.56 & 0.00 & 0.00 & 0.00 \\
\hline Lithuania & 77.73 & 0.00 & 13.45 & 6.96 & 1.86 & 0.00 & 0.00 & 0.00 \\
\hline Hungary & 6.24 & 0.00 & 17.68 & 67.37 & 3.89 & 4.80 & 0.00 & 0.03 \\
\hline Poland & 30.45 & 0.00 & 14.53 & 51.54 & 3.48 & 0.00 & 0.01 & 0.00 \\
\hline Romania & 97.98 & 0.00 & 1.48 & 0.53 & 0.00 & 0.00 & 0.00 & 0.00 \\
\hline Slovenia & 95.34 & 0.00 & 0.00 & 2.42 & 1.97 & 0.00 & 0.00 & 0.26 \\
\hline Slovakia & 89.19 & 0.00 & 0.09 & 9.57 & 0.54 & 0.35 & 0.00 & 0.27 \\
\hline
\end{tabular}

Table 5. Percentage share of individual RES in total production in 2015.

\begin{tabular}{ccccccccc}
\hline Countries & Hydro & Geothermal & Wind & $\begin{array}{c}\text { Primary } \\
\text { Solid } \\
\text { Biofuels }\end{array}$ & Biogases & $\begin{array}{c}\text { Renewable } \\
\text { Municipal } \\
\text { Waste }\end{array}$ & $\begin{array}{c}\text { Liquid } \\
\text { Biofuels }\end{array}$ \\
\hline & & & & & & & & \\
Solar \\
Bulgaria & 66.44 & 0.00 & 15.69 & 1.63 & 1.29 & 0.00 & 0.00 & 14.95 \\
Czechia & 28.71 & 0.00 & 5.35 & 19.55 & 24.41 & 0.81 & 0.00 & 21.16 \\
Estonia & 1.71 & 0.00 & 45.85 & 45.52 & 3.21 & 3.72 & 0.00 & 0.00 \\
Latvia & 66.99 & 0.00 & 5.30 & 13.6 & 14.1 & 0.00 & 0.00 & 0.01 \\
Lithuania & 43.52 & 0.00 & 34.42 & 13.51 & 3.65 & 1.78 & 0.00 & 3.10 \\
Hungary & 7.24 & 0.00 & 21.47 & 51.43 & 9.07 & 6.42 & 0.00 & 4.37 \\
Poland & 10.46 & 0.00 & 46.63 & 38.6 & 3.89 & 0.00 & 0.02 & 0.24 \\
Romania & 64.00 & 0.00 & 26.58 & 1.74 & 0.23 & 0.00 & 0.00 & 7.46 \\
Slovenia & 88.26 & 0.00 & 0.13 & 2.83 & 2.86 & 0.00 & 0.00 & 5.92 \\
Slovakia & 65.55 & 0 & 0.10 & 17.41 & 8.57 & 0.35 & 0.00 \\
\hline
\end{tabular}

Table 6. Percentage share of individual RES in total production in 2019.

\begin{tabular}{|c|c|c|c|c|c|c|c|c|}
\hline Countries & Hydro & Geothermal & Wind & $\begin{array}{l}\text { Primary } \\
\text { Solid } \\
\text { Biofuels }\end{array}$ & Biogases & $\begin{array}{c}\text { Renewable } \\
\text { Municipal } \\
\text { Waste }\end{array}$ & $\begin{array}{c}\text { Liquid } \\
\text { Biofuels }\end{array}$ & Solar \\
\hline \multicolumn{9}{|c|}{$\%$} \\
\hline Bulgaria & 42.48 & 0.00 & 16.54 & 19.41 & 2.90 & 0.56 & 0.00 & 18.11 \\
\hline Czechia & 28.30 & 0.00 & 6.24 & 21.38 & 22.54 & 0.93 & 0.00 & 20.61 \\
\hline Estonia & 0.89 & 0.00 & 32.07 & 58.81 & 1.81 & 2.99 & 0.00 & 3.43 \\
\hline Latvia & 66.02 & 0.00 & 4.82 & 18.01 & 11.04 & 0.00 & 0.00 & 0.10 \\
\hline Lithuania & 30.86 & 0.00 & 48.82 & 10.77 & 5.03 & 1.57 & 0.00 & 2.97 \\
\hline Hungary & 4.67 & 0.38 & 15.55 & 37.74 & 6.78 & 2.92 & 0.00 & 31.94 \\
\hline Poland & 10.18 & 0.00 & 57.74 & 24.62 & 4.34 & 0.40 & 0.01 & 2.72 \\
\hline Romania & 63.87 & 0.00 & 27.03 & 1.80 & 0.21 & 0.00 & 0.00 & 7.09 \\
\hline Slovenia & 89.31 & 0.00 & 0.12 & 2.89 & 1.80 & 0.00 & 0.10 & 5.78 \\
\hline Slovakia & 66.64 & 0.00 & 0.09 & 16.47 & 7.79 & 0.42 & 0.00 & 8.59 \\
\hline
\end{tabular}

\section{Results}

Using the algorithms discussed in the previous section, an analysis was conducted to select subgroups among the 10 selected countries (the new EU member states) based on eight variables characterizing percentage share of individual renewable energy sources in total renewable energy. The number of clusters was determined with the use of the Silhouette index. The index points to the adoption of two classes, it also seems reasonable to consider four clusters, because for $u=4, S(u)$ reaches the second maximum. 
Next, the countries were assigned to four clusters with the use of hierarchical clustering and Ward's method for each year-2010 (Figure 2), 2015 (Figure 3) and 2019 (Figure 4).
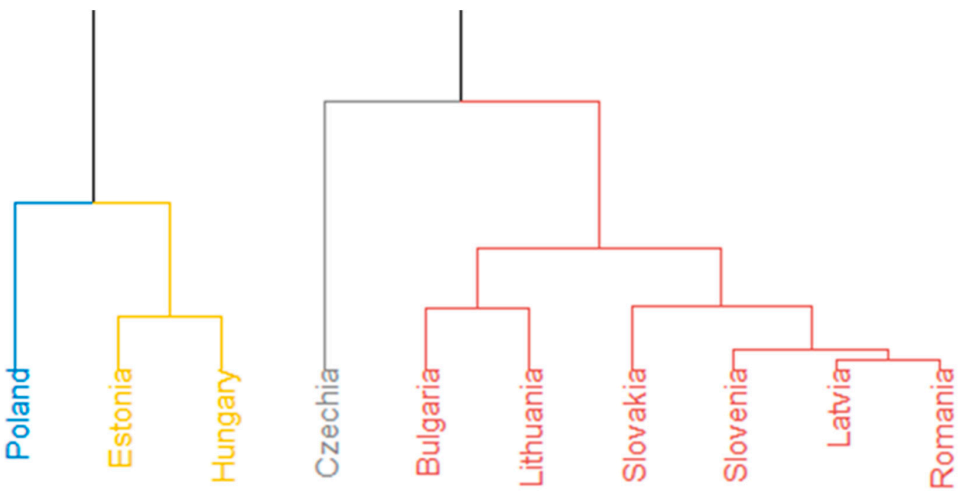

Figure 2. Results of the hierarchical grouping of similarities between the new member states in 2010.

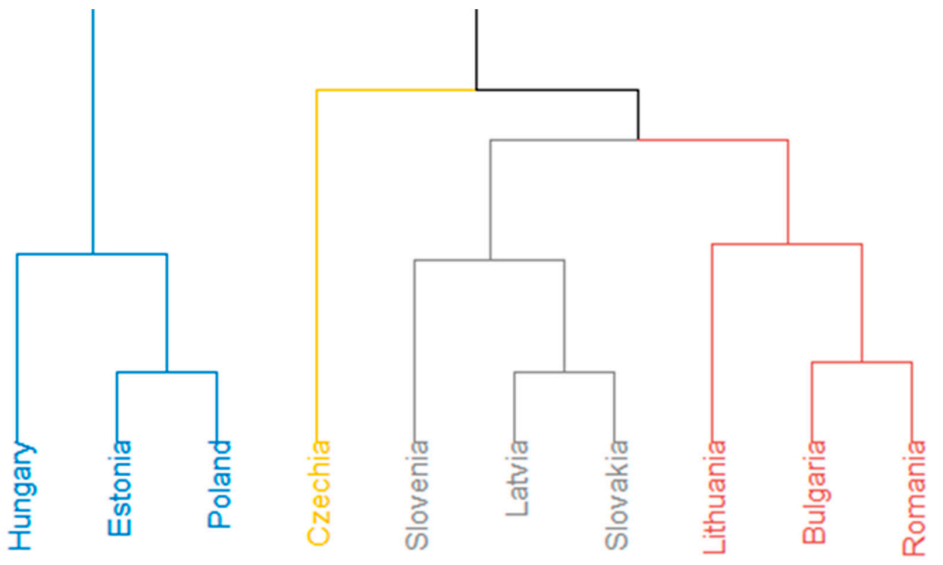

Figure 3. Results of the hierarchical grouping of similarities between the new member states in 2015.

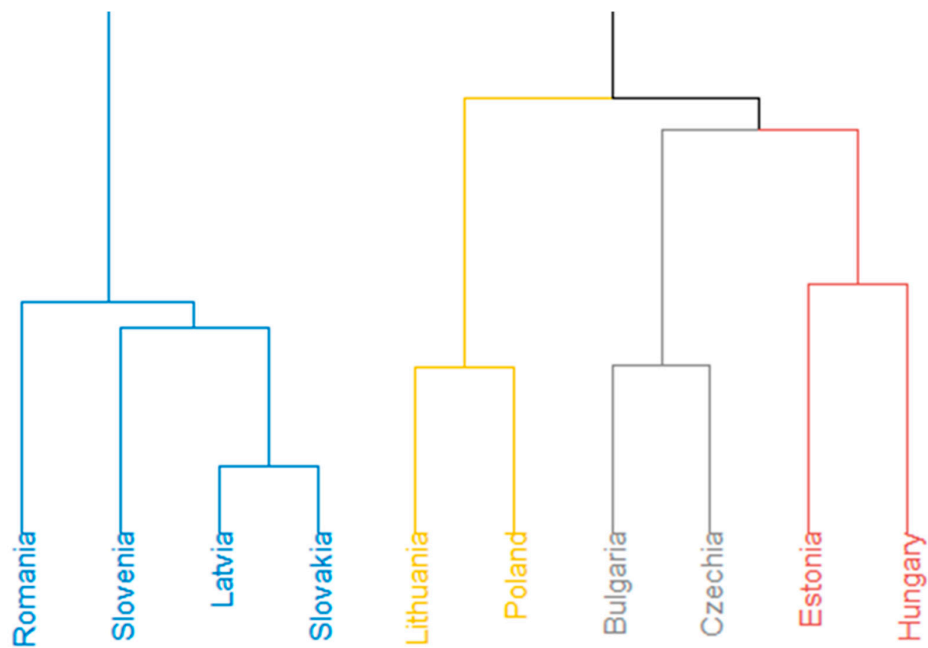

Figure 4. Results of the hierarchical grouping of similarities between the new member states in 2019.

In 2010 Poland was the only country assigned to the first group. In Poland the structure of renewable energy was determined by three sources: primary solid biofuels $(51.54 \%)$, hydro energy $(30.45 \%)$ and wind $(14.53 \%)$. In the second group were classified Estonia and Hungary. Their renewable energy sources were based mostly on primary solid biofuels and wind. The third group consists of Czechia (with 52.02\% of hydro energy and $22.98 \%$ 
on primary solid biofuels). It is worth noting that in Czechia the share of solar energy was $9.48 \%$, which was the highest value among all analyzed countries in this year. In the fourth cluster, Bulgaria, Lithuania, Slovakia, Slovenia, Latvia and Romania were classified. In these countries the hydro energy dominated over other considered energy sources.

The structure of renewable energy sources used in CEE new member states has been changing over time. This is due to the fact that these countries make new investments into renewable energy and create own new energetic policies. It is visible in the energy structure in 2015. According to the diagram presented in Figure 3, Czechia constitutes a separate group. In comparison to 2010, the renewable energy sources in Czechia are almost equally distributed among hydro energy, biogases, solar energy and primary solid biofuels. The first group, i.e., Hungary, Estonia and Poland, based their energy on primary solid biofuels and wind. Third group consists of Slovenia, Latvia and Slovakia. These countries used mainly hydro energy and primary solid biofuels and biogases. The last group: Lithuania, Bulgaria and Romania were primarily using hydro energy and wind.

In 2019 the first cluster included countries with over $60 \%$ share of renewable energy production from hydropower in the total renewable energy production (it must be added that taking into account the total electricity production from RES, hydropower is very important for the whole EU-currently it is the second largest RES; the source in this category that is more important is wind; wind and hydro power accounted for two-thirds of the total electricity generated from renewable sources in the EU). These countries include: Romania, Slovenia, Latvia and Slovakia. This group generally is very diversified taking into account energy from RES in its gross final consumption of energy as it includes Latvia, in which the share of energy production from RES in total energy production was the highest in the whole group selected for analysis, i.e., among the new member states countries in 2019. For analyses conducted for the whole EU, Latvia usually is placed among leaders (only Sweden and Finland could boast with better performance in that field) with its electricity sector is dominated by large hydropower plants on the Daugava River and cogeneration plants [77]. Slovakia is below the average in the EU-27 and Slovenia and Romania just above it, but still exceeding 20\% (Figure 1). Lithuania and Poland are the second cluster with the highest use of wind energy, but at the same time their share of renewable energy production in total energy production is highly diversified-for Poland it is the lowest among the new member states countries, while Lithuania is in the top three in this respect. Treating this part of the analysis as a kind of indicator of climate awareness, it has been found that Poland still has a lot of catching up to do, because as the study shows [50] high community involvement in ownership and management of energy projects can bring many benefits in RES development. The third cluster consisted of countries with a high percentage of the production of individual renewable energy sources in the production of total renewable energy, mainly from hydro, primary solid biofuels, solar and winds. Bulgaria and Czechia were included in this group. When taking into account the share of energy production from RES in total energy production the situation of both countries is different as Czechia is below the EU-27 average and Bulgaria exceeded it and the level of $20 \%$ as well (Figure 1). The fourth cluster includes countries where the percentage share of renewable energy from primary solid biofuels in the total renewable energy production is the highest among the analyzed countries. These include Estonia and Hungary. This is consistent with what Koppel and Ots [78] note in their paper claiming that Estonia has been successful in implementing biofuel programs. In the study [79], Hungary was treated as the country with the greatest potential among new member states countries in terms of geothermal development, for which it was projected about $19 \%$ share of geothermal in gross final consumption of RES in 2020. Even though this threshold was not reached, the successful development of projects in Hungary has shown that the relative ease of access to geothermal resources in the region means that there are real opportunities to develop this RES source. At the same time, as in the case of the second cluster, these countries occupy extremely different positions when it comes to their share of energy production from RES in total energy production (Figure 1). 


\section{Discussion}

In the energy production or consumption patterns and especially in the share of energy from RES one can find significant dissimilarities characterizing the countries of the CEE that from outside are still very often treated as a quite homogeneous region. Taking into account historical background of these countries, on the one hand, they are (or rather were) characterized by significant economic similarities (like significant development gap towards the EU, reflected in the differences in GDP per capita between most of 'old' and 'new' member states and its regions; followed by development ambitions and strategies based on the integration with the EU), and by social, environmental or economic differences, on the other hand. Undoubtedly, the connecting point for all countries selected for analysis is their membership in the EU, which results in the need for the adoption of many regulations in the area of environmental protection and organization of the energy sector, which has and will clearly translate into the energy sector.

The analysis covered 10 new EU member states, among which Poland and Romania had the highest absolute values of energy generated from RES in 2019 (Table 1). However, these values do not mean that these countries had a distinctive large share of RES in final energy compared to the remaining countries. For example, this share was only $12.2 \%$ for Poland in 2019 (Figure 1). It must be added that the data prove that the situation among the new members states concerning not only the share of RES is diversified, but the changes are recorded at a different pace (Table 7). The illustration of the situation for 2019 has been included in Figure 1.

Table 7. Percentage share of energy from renewable sources in the new member states in 2010, 2015, 2019. Source: data from Eurostat (online data code: NRG_IND_REN_custom_1595802).

\begin{tabular}{cccc}
\hline & & Year & $\mathbf{2 0 1 9}$ \\
\cline { 2 - 3 } Country & $\mathbf{2 0 1 0}$ & $\mathbf{2 0 1 5}$ & 21.56 \\
& 13.93 & 18.26 & 16.24 \\
Bulgaria & 10.51 & 15.07 & 31.89 \\
Czechia & 24.60 & 28.53 & 40.98 \\
Estonia & 30.38 & 37.54 & 25.46 \\
Latvia & 19.64 & 25.75 & 12.61 \\
Lithuania & 12.74 & 14.50 & 12.16 \\
Hungary & 9.30 & 11.89 & 24.29 \\
Poland & 22.83 & 24.79 & 21.97 \\
Romania & 21.08 & 22.88 & 16.89 \\
Slovenia & 9.10 & 12.88 & \\
Slovakia & & & \\
\hline
\end{tabular}

The leader for the 2010 was Latvia with the share of energy from RES of over $30 \%$ and this country stayed at the first position also in 2019 exceeding $40 \%$, which makes the change more than 10 p.p. Not a single country from the analyzed group of the new member stated reached such a result. There was also a country that recorded a decrease in the share of energy from RES in 2019 compared to 2010 and it was Hungary. The share calculated for Lithuania, Romania and Slovenia in 2019 was slightly worse for those countries compared with their performance in 2015. It proves that changes in the analyzed sector in some countries require a lot of time and effort as generally their pace in quite slow. Lack of continuous improvement and high variability recorded for some countries proves that there is a need for a more consistent policy of support for RES in those countries.

To reflect the actual state of renewable energy in new member states more accurately, the percentage share of individual renewable energy sources in total production from RES were analyzed in the above study. Such an approach gives a better and more objective insight into the state of this energy sector and should allow to undertake activities of similar nature in relation to internal energy production, technological development or common energy policy (national action plans). Taking into account the percentage share of individual renewable energy sources, new member states countries were divided into 
four clusters that were characterized by some similarity taking into account share of individual renewable energy sources in total renewable energy. In other words, countries of comparable specificity were defined, as the analysis showed those clusters included diversified countries taking into account the overall performance (understood as share of energy from RES as \% of gross final energy consumption). The results proved that the group of the new member states was not homogeneous. What is more, the structure of energy sources from RES is very unstable over time and even small changes were reflected in cluster analysis. resulting in a different grouping. The most current analysis has been carried out based on data for the 2019. In this year for Lithuania and Poland almost 50\% of their RES was based on wind. Romania, Slovenia, Latvia and Slovakia use mainly hydro energy and primary solid biofuels and biogases, although Romania is more widely using wind energy. Bulgaria and Czechia constitute a separate group, as they rely mainly on hydro energy, biogases, solar energy and primary solid biofuels. The last group, consisting of Estonia and Hungary use mainly primary solid biofuels, wind, and additionally Hungary was using solar energy most intensively (31.94\%).

The analyses presented should support this process by considering the needs and opportunities of the identified clusters of similar countries. This creates the possibility of a more efficient use of resources than if all countries were treated according to the same criterion. The problem of the proper energy transformation of the selected countries is important because many studies show a bidirectional relationship between aggregate renewable energy and real GDP $[41,80,81]$. Energy is one of the key factors shaping an economy's ability to grow. Therefore, it is important to maintain stability in the operation of this sector.

It must be stated that the renewable energy policy conducted by the EU takes into account differences in potentials of its member states. Member states should follow the obligations set for them in renewable energy directives. Until the end of June 2021 it was Directive 2009/28/EC of the European Parliament and of the Council of 23 April 2009 on the promotion of the use of energy from renewable sources and amending and subsequently repealing Directives 2001/77/EC and 2003/30/E that were repealed by Directive (EU) 2018/2001 of the European Parliament and of the Council of 11 December 2018 on the promotion of the use of energy from renewable sources. Long-term goals were set for the whole community (a 20\% share of its gross final energy consumption from renewable sources by 2020 and a $32 \%$ by 2030) but their 'distribution' between EU member states is based on national actions plans that express the individual pathways to development of RES in each member state. As shown, individual countries have different resources, their energy markets also differ in terms of size and characteristics. The performance in the field recorded by the countries of the CEE is therefore diversified, but it must be stressed once again that among 14 member states that had reached their national targets, half of the countries are located in the region of analysis (Bulgaria, Czechia, Estonia, Latvia, Lithuania, Romania and Slovakia). Hungary was very close to the target, and the countries that are furthest from meeting their targets belong to the group of old member states-France, Ireland and the Netherlands [82].

\section{Conclusions}

Energy production is moving toward renewables. Fossil fuels are gradually taking a step back giving way to more environmentally friendly resources. The European Union has chosen to be an active player in this transition, and although there are difficulties along the way, all member states are moving in the same direction, which is the creation of a new and efficient energy system. A common feature of the new member states analyzed in the article is that winter heating still involves heavy use of fossil fuels such as coal or gas, although it is known that less pollution leads to a healthier atmosphere. The benefits are positive for both restoring the local ecosystem and improving human health. In this context, RES offers great opportunities, but requires proper use and support from the government. This is because CEE countries diverge the most from the most developed 
EU countries $[54,83]$. Therefore, it is an area that should be of particular interest within the framework of energy policy, although the implementation of these goals will require very high investment outlays. However, increasing use of renewable energy will help economies in transition achieve both economic growth and clean environment goals [84].

It is quite understandable that moving to renewable energy will not be possible in each country totally or/and at the same pace. The disadvantages of RES (especially high costs of such technologies upfront and storage compared to traditional energy and geographical limitations), as well as some other economic, social or political issues (like those connected with local labor markets). The circumstances of increasing the share of RES in the energy system are very complex and the evaluation of the energy sector is capital intensive and includes expensive installations. Their rapid replacement does not pay off until there is a return on invested capital. This may also explain why of some of the economies studied are so reluctant to the proposed changes.

The results of the research presented in this article are intended to see the structure of renewable energy production in new member states in the context of their national energy transformations. The presented approach to the analysis of energy production, taking into account the demographic and economic potential of individual countries, enabled the acquisition of new knowledge in this field and supported the assessment of the current state of RES. It also showed the diversity of these countries. Countries with similar problems need to take action of a similar nature in relation to internal energy production, technological development or community policy. Investments should be made to promote the purchase and use of RES installations, such as a system of subsidies or regulatory mechanisms. In addition, commonality across countries in the region may increase the available potential for RES development in these countries combined, improve their energy security and consolidate sustainable development. It seems that cooperation in the form of joint projects or joint support systems should be intensified.

Recently, in the statement for the UN Climate Change Conference in Glasgow (COP26) President von der Leyen underlined that "there is an encouraging message that shows that you can cut emissions and prosper" and that a number of new actions will be launched with other countries worldwide, also in order to develop renewables earlier and faster [85]. This proved that the EU incessantly aims at becoming a role model in the analyzed area. Some of the CEE countries can indeed boast of being good examples in the field of RES development.

Author Contributions: Conceptualization, A.W., A.I.-S.; methodology, A.W., A.I.-S.; formal analysis, A.W.; writing — original draft preparation, A.W., A.I.-S.; writing—review and editing, A.W., A.I.-S.; visualization, A.W., A.I.-S. All authors have read and agreed to the published version of the manuscript.

Funding: This research received no external funding.

Institutional Review Board Statement: Not applicable.

Informed Consent Statement: Not applicable.

Data Availability Statement: All data are contained within the article.

Conflicts of Interest: The authors declare no conflict of interest.

\section{References}

1. Ellabban, O.; Abu-Rub, H.; Blaabjerg, F. Renewable Energy Resources: Current Status, Future Prospects and Their Enabling Technology. Renew. Sustain. Energy Rev. 2014, 39, 748-764. [CrossRef]

2. Türkoğlu, S.P.; Kardoğan, P.S.Ö. The Role and Importance of Energy Efficiency for Sustainable Development of the Countries. In Proceedings of the 3rd International Sustainable Buildings Symposium (ISBS 2017); Firat, S., Kinuthia, J., Abu-Tair, A., Eds.; Springer International Publishing: Cham, Switzerland, 2018; pp. 53-60. Available online: https:/ /www.researchgate.net/publication/ 324110795_The_Role_and_Importance_of_Energy_Efficiency_for_Sustainable_Development_of_the_Countries (accessed on 15 October 2021). 
3. Sasana, H.; Ghozali, I. The Impact of Fossil and Renewable Energy Consumption on the Economic Growth in Brazil, Russia, India, China and South Africa. Int. J. Energy Econ. Policy 2017, 7, 194-200.

4. Ahuja, D.; Tatsutani, M. Sustainable energy for developing countries. SAPIENS Surv. Perspect. Integr. Environ. Soc. 2009, 2, 1-16.

5. Staffell, I.; Scamman, D.; Abad, A.V.; Balcombe, P.; Dodds, P.E.; Ekins, P.; Shah, N.; Ward, K.R. The Role of Hydrogen and Fuel Cells in the Global Energy System. Energy Environ. Sci. 2019, 12, 463-491. [CrossRef]

6. Goldstone, J.A. The Rise of the West-Or Not? A Revision to Socio-Economic History. Sociol. Theory 2000, 18, 175-194. [CrossRef]

7. Androniceanu, A.-M.; Kinnunen, J.; Georgescu, I.; Androniceanu, A. A Multidimensional Approach to Competitiveness, Innovation and Well-Being in the EU Using Canonical Correlation Analysis. J. Compet. 2020, 12, 5-21. [CrossRef]

8. Ntanos, S. Renewable Energy Consumption, Carbon Dioxide Emissions and Economic Growth: Evidence from Europe and Greece. Proc. e-RA 2015, 10, 46-56.

9. Zou, C.; Qun, Z.; Zhang, G.; Xiong, B. Energy Revolution: From a Fossil Energy Era to a New Energy Era. Nat. Gas Ind. B 2016, 3, 1-11. [CrossRef]

10. Rousseau, S.; Deschacht, N. Public Awareness of Nature and the Environment during the COVID-19 Crisis. Environ. Resour. Econ. 2020, 76, 1149-1159. [CrossRef]

11. Ramanathan, V.; Carmichael, G. Global and Regional Climate Changes Due to Black Carbon. Nat Geosci. 2008, 1, $221-227$. [CrossRef]

12. Bölük, G.; Mert, M. Fossil \& Renewable Energy Consumption, GHGs (Greenhouse Gases) and Economic Growth: Evidence from a Panel of EU (European Union) Countries. Energy 2014, 74, 439-446. [CrossRef]

13. Arndt, C.; Arent, D.; Hartley, F.; Merven, B.; Mondal, A.H. Faster Than You Think: Renewable Energy and Developing Countries. Annu. Rev. Resour. Econ. 2019, 11, 149-168. [CrossRef]

14. Inglesi-Lotz, R. The Impact of Renewable Energy Consumption to Economic Growth: A Panel Data Application. Energy Econ. 2016, 53, 58-63. [CrossRef]

15. Fernández González, P.; Landajo, M.; Presno, M.J. Tracking European Union $\mathrm{CO}_{2}$ Emissions through LMDI (Logarithmic-Mean Divisia Index) Decomposition. The Activity Revaluation Approach. Energy 2014, 73, 741-750. [CrossRef]

16. Huhta, K. The Scope of State Sovereignty under Article 194(2) TFEU and the Evolution of EU Competences in the Energy Sector. Int. Comp. Law Q. 2021, 70, 991-1010. [CrossRef]

17. Available online: https://www.consilium.europa.eu/en/press/press-releases/2020/07/05/climate-transition-transformationand-convergence-europe-s-path-towards-robust-resilience-speech-of-president-charles-michel/ (accessed on 7 November 2021).

18. Pietrzak, M.; Balcerzak, A.; Gajdos, A.; Arendt, L. Entrepreneurial Environment at Regional Level: The Case of Polish Path towards Sustainable Socio-Economic Development. Entrep. Sustain. Issues 2017, 5, 190-203. [CrossRef]

19. Chocholatá, M.; Furková, A. The Analysis of Employment Rates in the Context of Spatial Connectivity of the EU Regions. Equilib. Q. J. Econ. Econ. Policy 2018, 13, 181-213. [CrossRef]

20. Grybaitè, V.; Stankevičienė, J. An Empirical Analysis of Factors Affecting Sharing Economy Growth. Oeconomia Copernic. 2018, 9 , 635-654. [CrossRef]

21. Kuc, M. Is the Regional Divergence a Price for the International Convergence? J. Compet. 2017, 9, 50-65. [CrossRef]

22. Kijek, A.; Matras-Bolibok, A. Technological Convergence across European Regions. Equilib. Q. J. Econ. Econ. Policy 2020, 15, 295-313. [CrossRef]

23. Kacperska, E.; Łukasiewicz, K.; Pietrzak, P. Use of Renewable Energy Sources in the European Union and the Visegrad Group Countries-Results of Cluster Analysis. Energies 2021, 14, 5680. [CrossRef]

24. Nicolini, M.; Tavoni, M. Are Renewable Energy Subsidies Effective? Evidence from Europe. Renew. Sustain. Energy Rev. 2017, 74, 412-423. [CrossRef]

25. Kuzemko, C.; Bradshaw, M.; Bridge, G.; Goldthau, A.; Jewell, J.; Overland, I.; Scholten, D.; Van de Graaf, T.; Westphal, K. COVID-19 and the Politics of Sustainable Energy Transitions. Energy Res. Soc. Sci. 2020, 68, 101685. [CrossRef]

26. Lund, H. Renewable energy strategies for sustainable development. Energy 2007, 32, 912-919. [CrossRef]

27. Włodarczyk, B.; Firoiu, D.; Ionescu, G.H.; Ghiocel, F.; Szturo, M.; Markowski, L. Assessing the Sustainable Development and Renewable Energy Sources Relationship in EU Countries. Energies 2021, 14, 2323. [CrossRef]

28. World Commission on Environment and Development. Report of the World Commission on Environment and Development: Our Common Future. Available online: https://sustainabledevelopment.un.org/content/documents/5987our-common-future.pdf (accessed on 18 November 2021).

29. Sneddon, C.; Howarth, R.B.; Norgaard, R.B. Sustainable development in a post-Brundtland world. Ecol. Econ. 2006, 57, 253-268. [CrossRef]

30. Choy, Y.K. 28 years into "Our Common Future": Sustainable development in the post-Brundtland world. Sustain. Dev. 2015, 2, $1197-1211$

31. Sathaye, J.; Lucon, O.; Rahman, A.; Christensen, J.; Denton, F.; Fujino, J.; Heath, G.; Mirza, M.; Rudnick, H.; Schlaepfer, A. Potsdam Institute for Climate Impact Research Renewable Energy in the Context of Sustainable Development. Physics Faculty Publications. Paper 1. 2011. Available online: https:/ / ecommons.udayton.edu/phy_fac_pub/1 (accessed on 18 November 2021).

32. Wang, Q.; Yang, X. Investigating the sustainability of renewable energy-An empirical analysis of European Union countries using a hybrid of projection pursuit fuzzy clustering model and accelerated genetic algorithm based on real coding. J. Clean. Prod. 2020, 268, 121940. [CrossRef] 
33. Anders, I.; Stagl, J.; Auer, I.; Pavlik, D. Climate Change in Central and Eastern Europe. In Managing Protected Areas in Central and Eastern Europe under Climate Change. Advances in Global Change Research; Rannow, S., Neubert, M., Eds.; Springer: Dordrecht, The Netherlands, 2014; Volume 58. [CrossRef]

34. Bagliani, M.; Dansero, E.; Puttilli, M. Territory and energy sustainability: The challenge of renewable energy sources. J. Environ. Plan. Manag. 2010, 53, 457-472. [CrossRef]

35. Kumar, M. Social, Economic, and Environmental Impacts of Renewable Energy Resources, Wind Solar Hybrid Renewable Energy System, Kenneth Eloghene Okedu, Ahmed Tahour and Abdel Ghani Aissaou; IntechOpen: London, UK, 2020; Available online: https: / /www. researchgate.net/publication/339064877_Social_Economic_and_Environmental_Impacts_of_Renewable_Energy_Resources (accessed on 15 October 2021). [CrossRef]

36. Sheikh, N.J.; Kocaoglu, D.F.; Lutzenhiser, L. Social and Political Impacts of Renewable Energy: Literature Review. Technol. Forecast. Soc. Chang. 2016, 108, 102-110. [CrossRef]

37. Butturi, M.A.; Lolli, F.; Sellitto, M.A.; Balugani, E.; Gamberini, R.; Rimini, B. Renewable Energy in Eco-Industrial Parks and Urban-Industrial Symbiosis: A Literature Review and a Conceptual Synthesis. Appl. Energy 2019, 255, 113825. [CrossRef]

38. Dudin, M.; Frolova, E.; Protopopova, O.; Mamedov, O.; Odintsov, S. Study of Innovative Technologies in the Energy Industry: Nontraditional and Renewable Energy Sources. Entrep. Sustain. Issues 2019, 6, 1704-1713. [CrossRef]

39. Cucchiella, F.; D'Adamo, I.; Gastaldi, M.; Koh, S.L.; Rosa, P. A Comparison of Environmental and Energetic Performance of European Countries: A Sustainability Index. Renew. Sustain. Energy Rev. 2017, 78, 401-413. [CrossRef]

40. García-Álvarez, M.T.; Moreno, B.; Soares, I. Analyzing the Environmental and Resource Pressures from European Energy Activity: A Comparative Study of EU Member States. Energy 2016, 115, 1375-1384. [CrossRef]

41. Ohler, A.; Fetters, I. The Causal Relationship between Renewable Electricity Generation and GDP Growth: A Study of Energy Sources. Energy Econ. 2014, 43, 125-139. [CrossRef]

42. Kula, F. The Long-Run Relationship between Renewable Electricity Consumption and GDP: Evidence from Panel Data. Energy Sources Part B Econ. Plan. Policy 2014, 9, 156-160. [CrossRef]

43. Anwar, A.; Arshed, N.; Kousar, N. Renewable Energy Consumption and Economic Growth in Member of OIC Countries. Eur. Online J. Nat. Soc. Sci. 2017, 6, 111-129.

44. Stiglitz, J.E.; Sen, A.; Fitoussi, J.-P. Report by the Commission on the Measurement of Economic Performance and Social Progress. 2009. Available online: https:/ / ec.europa.eu/eurostat/documents/8131721/8131772/Stiglitz-Sen-Fitoussi-Commission-report. pdf (accessed on 18 November 2021).

45. Fleurbaey, M. Beyond GDP: The quest for the measure of social welfare. J. Econ. Lit. 2009, 47, 1029-1075. [CrossRef]

46. Unteutsch, M.; Lindenberger, D. Promotion of Electricity from Renewable Energy in Europe Post 2020. The Economic Benefits of Cooperation. In Interdisziplinäre Aspekte der Energiewirtschaft; von Weizsäcker, C.C., Lindenberger, D., Höffler, F., Eds.; Energie in Naturwissenschaft, Technik, Wirtschaft und Gesellschaft; Springer Fachmedien: Wiesbaden, Germany, 2016; pp. 61-78. ISBN 978-3-658-12726-8.

47. Cucchiella, F.; D'Adamo, I.; Gastaldi, M. Future Trajectories of Renewable Energy Consumption in the European Union. Resources 2018, 7, 10. [CrossRef]

48. Gurkov, I. Transition Economy. In Wiley Encyclopedia of Management; American Cancer Society: Chichester, UK, 2015; ISBN 978-1-118-78531-7.

49. Faaij, A.P.C. Bio-Energy in Europe: Changing Technology Choices. Energy Policy 2006, 34, 322-342. [CrossRef]

50. Walker, G.; Devine-Wright, P. Community Renewable Energy: What Should It Mean? Energy Policy 2008, 36, 497-500. [CrossRef]

51. Burke, M.J.; Stephens, J.C. Political Power and Renewable Energy Futures: A Critical Review. Energy Res. Soc. Sci. 2018, 35, 78-93. [CrossRef]

52. Shao, X.; Fang, T. Performance Analysis of Government Subsidies for Photovoltaic Industry: Based on Spatial Econometric Model. Energy Strategy Rev. 2021, 34, 100631. [CrossRef]

53. Bersalli, G.; Menanteau, P.; El-Methni, J. Renewable Energy Policy Effectiveness: A Panel Data Analysis across Europe and Latin America. Renew. Sustain. Energy Rev. 2020, 133, 110351. [CrossRef]

54. Brodny, J.; Tutak, M. Analyzing Similarities between the European Union Countries in Terms of the Structure and Volume of Energy Production from Renewable Energy Sources. Energies 2020, 13, 913. [CrossRef]

55. Armeanu, D.Ş.; Vintilă, G.; Gherghina, Ş.C. Does Renewable Energy Drive Sustainable Economic Growth? Multivariate Panel Data Evidence for EU-28 Countries. Energies 2017, 10, 381. [CrossRef]

56. Simionescu, M.; Strielkowski, W.; Tvaronavičienè, M. Renewable Energy in Final Energy Consumption and Income in the EU-28 Countries. Energies 2020, 13, 2280. [CrossRef]

57. Pakulska, T. Green Energy in Central and Eastern European (CEE) Countries: New Challenges on the Path to Sustainable Development. Energies 2021, 14, 884. [CrossRef]

58. Nikolaev, A.; Konidari, P. Development and Assessment of Renewable Energy Policy Scenarios by 2030 for Bulgaria. Renew. Energy 2017, 111, 792-802. [CrossRef]

59. Al-Mansour, F.; Sucic, B.; Pusnik, M. Challenges and Prospects of Electricity Production from Renewable Energy Sources in Slovenia. Energy 2014, 77, 73-81. [CrossRef] 
60. Câmpeanu, V.; Pencea, S. Renewable Energy Sources in Romania: From a "Paradise" of Investors to a Possible Abandon or to Another Boom? The Impact of a New Paradigm in Romanian Renewable Sources Policy. Procedia Econ. Financ. 2014, 8, 129-137. [CrossRef]

61. Everitt, B.S.; Landau, S.; Leese, M.; Stahl, D. Cluster Analysis, 5th ed.; John Wiley \& Sons, Ltd.: Chichester, UK, 2011; ISBN 978-0-470-97844-3.

62. Hartigan, J.A. Clustering Algorithms; Wiley: John Wiley and Sons, Inc.: New York, NY, USA, 1975; ISBN 978-0-471-35645-5.

63. Semenenko, I.; Halhash, R.; Sieriebriak, K. Sustainable Development of Regions in Ukraine: Before and after the Beginning of the Conflict. Equilib. Q. J. Econ. Econ. Policy. 2019, 14, 317-339. [CrossRef]

64. Kuc, M. The Use of Taxonomy Methods for Clustering European Union Countries Due to the Standard of Living. Oeconomia Copernic. 2012, 3, 5-24. [CrossRef]

65. MacKay, D. Information Theory, Inference, and Learning Algorithms; Cambridge University Press: Cambridge, UK, 2003; Volume 50, ISBN 978-0-521-64298-9. Available online: https://inst.eecs.berkeley.edu// \{\}ee121/sp08/handouts/it.pdf (accessed on 18 October 2021).

66. Miłek, D. Spatial Differentiation in the Social and Economic Development Level in Poland. Equilib. Q. J. Econ. Econ. Policy 2018, 13, 487-507. [CrossRef]

67. Szymańska, A. National Fiscal Frameworks in the Post-Crisis European Union. Equilib. Q. J. Econ. Econ. Policy 2018, 13, 623-642. [CrossRef]

68. Rollnik-Sadowska, E.; Dabrowska, E. Cluster Analysis of Effectiveness of Labour Market Policy in the European Union. Oeconomia Copernic. 2018, 9, 143-158. [CrossRef]

69. Ward, J.H. Hierarchical Grouping to Optimize an Objective Function. J. Am. Stat. Assoc. 1969, 58, 236-244. [CrossRef]

70. Małkowska, A.; Głuszak, M. Pro-investment Local Policies in the Area of Real Estate Economics-Similarities and Differences in the Strategies Used by Communes. Oeconomia Copernic. 2016, 7, 269-283. [CrossRef]

71. Reiff, M.; Surmanová, K.; Balcerzak, A.P.; Pietrzak, M. Multiple criteria analysis of European Union agriculture. J. Int. Stud. 2016, 9, 62-74. [CrossRef] [PubMed]

72. Starczewski, A.; Krzyżak, A. Performance Evaluation of the Silhouette Index. In Proceedings of the Artificial Intelligence and Soft Computing; Rutkowski, L., Korytkowski, M., Scherer, R., Tadeusiewicz, R., Zadeh, L.A., Zurada, J.M., Eds.; Springer International Publishing: Cham, Switzerland, 2015; pp. 49-58.

73. Dudek, A. Silhouette Index as Clustering Evaluation Tool. In Proceedings of the Classification and Data Analysis; Jajuga, K., Batóg, J., Walesiak, M., Eds.; Springer International Publishing: Cham, Switzerland, 2020; pp. 19-33.

74. Mamat, A.R.; Mohamed, F.S.; Mohamed, M.A.; Rawi, N.M.; Awang, M.I. Silhouette Index for Determining Optimal K-Means Clustering on Images in Different Color Models. Int. J. Eng. Technol. 2018, 7, 105-109. [CrossRef]

75. Ivaničová, Z.; Kalužák, L. Dynamika vývoja krajín Eurozóny na základe vybraných odsovatel’ov. Ekon. Rozhl’ady 2015, 44, 476-492.

76. Reiff, M.; Surmanová, K. Cluster Analysis of EE Agriculture. In Proceedings of the International Scientific Conference Quantitative Methods in Economics Multiple Criteria Decision Making XVIII, Vrátna, Slovakia, 25-27 May 2016; pp. $322-326$.

77. Kasiulis, E.; Punys, P.; Kvaraciejus, A.; Dumbrauskas, A.; Jurevičius, L. Small Hydropower in the Baltic States-Current Status and Potential for Future Development. Energies 2020, 13, 6731. [CrossRef]

78. Koppel, M.; Ots, M. Use of renewable energy sources in Estonia. In Investigation and Usage of Renewable Energy Sources. First Conference Proceedings; Estonian Agricultural University: Tartu, Estonia, 4 November 1999; pp. 10-20. ISBN 9985-882-63-6.

79. Pająk, L.; Kepińska, B.; Kasztelewicz, A.; Bujakowski, W.; Tomaszewska, B.; Hołojuch, G. Some Factors Determining the Geothermal Energy Uses' Development in the Central and Eastern European Countries in Coming Years. Zesz. Nauk. Inst. Gospod. Surowcami Miner. Energia PAN 2016, 92, 337-357.

80. Matei, I. Is There a Link between Renewable Energy Consumption and Economic Growth? A Dynamic Panel Investigation for the OECD Countries. Rev. Econ. Polit. 2017, 127, 985-1012. [CrossRef]

81. Liu, W.-C. The Relationship between Primary Energy Consumption and Real Gross Domestic Product: Evidence from Major Asian Countries. Sustainability 2020, 12, 2568. [CrossRef]

82. Available online: https://www.eea.europa.eu/data-and-maps/indicators/renewable-gross-final-energy-consumption-5/ assessment (accessed on 7 November 2021).

83. Boltho, A. Southern and Eastern Europe in the Eurozone: Convergence or Divergence? Balt. J. Econ. 2020, 20, 74-93. [CrossRef]

84. Adedoyin, F.; Abubakar, I.; Bekun, F.V.; Sarkodie, S.A. Generation of Energy and Environmental-Economic Growth Consequences: Is There Any Difference across Transition Economies? Energy Rep. 2020, 6, 1418-1427. [CrossRef]

85. Available online: https:/ / ec.europa.eu/commission/presscorner/detail/en/STATEMENT_21_5643 (accessed on 7 November 2021). 